\title{
Çocuklara Yönelik Etkileşimli E-Kitap Uygulamaları
}

Doç. Özden Pektaş Turgut

Makale Geliş Tarihi: 22.05.2018 Yayına Kabul Tarihi: 30.05 .2018

\section{Özet}

Matbaa ve bilgisayar teknolojilerindeki gelişmelere paralel olarak değişen yayıncllık biçimleri, günümüzde kâ̆ı̆da bă̆ımlı olmaktan çıkarak bilginin işlenmesinde, depolanmasında veya dağııımında elektronik ortam araçlarının etkin kullanıldığı bir yapıya dönüsmüsstür. Bunun yanı sıra hızlı tüketim alışanlıkları, mobil cihazların artışı bir çok kitap, gazete, dergi gibi basılı ürünün, elektronik ortamda izlenmek üzere taşınabilir cihazlara ve akılı telefonlara özel biçimde tasarlanması gerekliliğini de doğurmuştur. Dünyada giderek artan pazar payı ile elektronik kitaplar, basılı sürümlerine ciddi rakip oluşturacağı öngörülen yayıncılık sektörünün geleceği parlak mecrası olarak nitelendirilmektedir. E-kitap okuma cihazlarının çeșitliliği, donanım ve yazılım açısından sürekli eklenen gelişmiş özellikler sayesinde okuma alıskanlıkları biçim değistirmistir. Yetiskinlere yönelik çok sayıdaki e-kitap örneğinin yanı sıra özellikle çocuk okurları merkezine alan yayınevleri, edebiyat klasiklerinden eğitim içerikli öğretici yayınlara kadar bir çok kitabın etkileşimli tasarlanmış yeni uygulamalarını piyasaya sürmektedir. Alanın en dikkat çeken örnekleri, özellikle okul öncesi çocuklara yönelik hazırlanan etkileşimli hikaye kitapları ve öğretici dijital uygulamalardır. Bu çalışma alana yönelik tasarlanan örneklerin grafik tasarım ilkeleri çerçevesinde incelenmesini içermektedir.

Anahtar Kelimeler: E-Yayıncılık, E-Kitap, Etkileşimli Uygulamalar, Çokluortam Tasarımı

\section{INTERACTIVE E-BOOK APPLICATIONS FOR CHILDREN}

\section{Abstract}

As a parallel situation to the developments in printing \& computer technology, publishing formats has been also changed regardless of paper and transformed into a new form. The structure of information has been turned to processed, stored and distributed actively by electronic media tools. Besides rapid consumer habits and increment of mobile devices; books, newspapers, printed products such as magazines needed to be designed in speciality to monitored electronically for mobile devices\&smart phones. Electronic books with gradually increased market share described as a brilliant media which is projected to be a serious competitor to the printed version in the future of the publishing industry The reading habits have been changed up to the variety of e-book reading devices and advanced features being added in terms of hardware \& software formats. As well as the adult readers, publishers attach importance to the children publishing in the mean of educational content and well publishers attach importance to the children publishing in the mean of educational content and well
known literary classics that designed as interactive applications for mobile to serve in the market. The most prominent examples of this area are particularly interactive story books and educational digital applications for preschool children. This study includes the examination of specimens designed for the field according to the method of research from the framework of graphic design principles.

Keywords: E-Publishing, E-Book, Interactive Applications, Multimedia Design

Doç. Özden Pektaş Turgut, Hacettepe Üniversitesi, Güzel Sanatlar Fakültesi, Grafik Bölümü, Ankara 


\section{Giriş}

20. yüzyıl sonlarına doğru ortaya çıkan İnternetin, gelişen bir iletişim aracı olarak tüm dünyayı sardığı, hayatımızın hemen her alanına girerek yaygınlaştığı bir gerçektir. Bilgiye ulaşma, çoğaltma ve yayma konusunda sağladığı olanaklar ve kolaylıklar, bu teknolojiyi yayımcılık sektörü için de vazgeçilmez bir araç haline getirmiştir. Gerek yazılı basının, gerekse görsel medyanın pahalı yatırımlarına ihtiyaç duymadan, çok küçük maliyetlerle yazılı ve görsel iletişim araçlarının tüm özelliklerini içeren yapısıyla elektronik yayıncılık, kitle iletişiminde önemli bir alandır. Genel hatlarıyla "bilgisayar temelinde oluşturulan, depolanan, işlenen ve güncellenen bilginin seçilmiş bir izleyici grubuna aktarımı" (Kist, 1989) olarak tanımlanan elektronik yayımcılık, çoklu ortam özellikleri ve İnternet erişimi sayesinde iletişim sürecini etkileşimli hale getirmektedir.

Elektronik yayıncılığın basılı ortama göre en büyük gücü şüphesiz güncellenebilirliğidir. Değişen gündemin akışına bağlı olarak anında yenilenen haberlerin elektronik cihazlar aracılığıyla iletimi, elektronik kağıt teknolojisinin reklam-pazarlama-ürün tasarımı gibi alanlarda farklı şekildeki kullanımları gün geçtikçe çoğalmaktadır. Basılı yayıncılığın büyük sorunu olan malzeme, üretim ve stok maliyetleri, tamamen elektronik olarak işleyen matbaa süreci ve siparişe bağlı olarak üretim (print-on-demand) seçenekleri ile üstesinden gelinmeye çalışılmaktadır. Teknolojideki bu hızlı gelişmeler elektronik cihazları günlük yaşamımızın vazgeçilmez parçası haline getirmiş, bilgiye en hızlı ve kısa sürede ulaşma isteğine paralel olarak okuma-yazma alışkanlıklarının da değişimine sebep olmuştur. Günümüzde e-gazeteler, e-dergiler ve e-kitapların kullanılırlığı, yaygınlığı basılı ortamdaki benzerleriyle rekabet edecek duruma gelmiştir.

Dijital medya olarak nitelendirilen, internet üzerinden dağıtılan her türlü görsel - işitsel içerik ve uygulamalarının 2018 yılında dünya genelinde 120,880 milyon dolarlık bir pazara ulaşacağı ön görülmektedir. Dünya'dan 50 ülkeye ait dijital medya kullanım verileri (internetten indirilen dijital videolar, çevrimiçi izlenen film, dinlenen müzik ve oyunları, e- yayın içeriklerinin tümü) kaynak alınarak yapılan araştırmada, pazarın en geniş bölümünü video oyunlar oluştururken, elektronik yayıncılık 2022'e kadar devam edeceği ön görülen istikrarlı artışı ile 2016 yılından bu yana konumunu korumaktadır ${ }^{1}$.

2018 yılı sonlarında 17,952 milyon dolarlık pazara ulaşacağı tahmin edilen elektronik yayıncılığın öne çıkan alt mecraları e-kitap, e-gazete ve e-kağıt

' Digital Media (2018). Web. https://wwwstatista.com/outlook/200/100/digital-media/worldwide adresinden 18 Mayıs 2018'de alınmııstir. olarak tanımlanmaktadır. Alt alan verilerinin karşılaştırıldığı araştırma sonuçlarına göre ise e-kitap 11.862 milyon dolar ile e-yayıncılık pazarında lider olma özelliğini korumaktadır².

\section{Elektronik Kitap Kullanımı}

15. yüzyılda Johannes Gutenberg'in hareketli hurufatı keşfetmesi ve devamında gelişen matbaanın sayesinde el yazması eserlerin basılarak kitaplaştırılması süreci, üretim ve dağıtımındaki hız yayıncılığın en önemli devrimidir. 19. yüzyılda gerçekleşen basım teknolojilerindeki yenilikler ve bilgisayar temelinde yürüyen matbaa sürecine paralel olarak yayıncılık anlayışı da zaman içerisinde değişerek, kâğıda bağımlı olmaktan çıkıp elektronik biçimlerde sunulmaya başlanmıştır. Bu sektörün lider mecrası elektronik kitap alanındaki en çarpıcı dönüm noktası ise tarihe atıfta bulunarak isimlendirilen Gutenberg Projesi'dir. Proje kapsamında, telif süresi dolmuş, yayınlanmasında ve dağıtımında sorun olmayan kitapların yer aldığı dijital bir kütüphane oluşturulmuştur. Ağırlıklı olarak dünya klasikleri ve akademik yayınlardan oluşan kütüphanede 50,000'nin üzerinde kitap konu başlıklarına göre kategorilere ayrılmış, ücretsiz biçimde indirilmesine veya çevrimiçi okunmasına olanak verilmektedir.

E-kitapların ortaya çıkısı ve kullanımı ile ilgili ilk gelişmeler 1987 yılında bilgisayar oyunları üreten bir firma olan Eastgate Systems'ın Michael Joyce'un "Afternoon" adlı kitabını diskette yayınlaması ve 1990 yılında Serendipity Systems'ın "PC-Book" isimli e-kitap görüntüleme programını geliştirmesiyle ortaya çıkmışır. 1992 yılında ise, e-kitaplar metin tabanlı DOS ortamından, grafik tabanlı Windows ortamındaki edisyonlara dönüştürülmüşve daha kolay okunabilecek bir biçime kavuşturulmuştur. E-kitap teknolojisindeki bu gelişmeleri 1993 yılında BiblioBytes'ın internet üzerinden e-kitap satmak üzere ilk web sitesini kurması, 1994 yılında e-kitap formatının metinden HTML'e geçişi ve aynı yıl içerisinde The Fiction Works adlı ilk e-kitap yayıncı şirketinin kurulması izlemiştir (Anameriç ve Rukancı, 2003: 150).

1990'lar sonrasında gelişen internet altyapısı ve HTML ile biçimlenen web sayfalarınındoğuşu, içeriksunumunundazenginleşmesineyönelikçalışmaları hızlandırmıştır. Başlangıçta internet üzerinden bilgisayar aracılığıyla erişilen ve okunan düz metin biçimindeki e-kitaplar zaman içerisinde değişerek yaratılan yazılım desteği ile özel cihazlarda görüntülenecek biçimlerde çeşitlenmiştir. Bu dönemde birçok yayınevi\&firma e-kitap okuyucu donanımlar geliştirerek dijital yayıncılığa ciddi yatırımlarda bulunmuş, kitap endüstrisinin gelişimine katkı sağlamıştır. 2000'li yıllardan itibaren kullanımı yaygınlaşan elektronik kitapların özellikle üretim maliyetlerinin

(2018). Web. https://www statista com/outlook/204/100/epublishing/worldwide adresinden 10 Mart 2018'de alınmısstir. 
düşük olması, kullanıcılar ve yazarlar açısından sağladığı avantajlar sebebiyle yayıncilık pazarındaki etkisi de giderek artmıştır. Devam eden süreçte e-kitap okuma cihazların yazılımsal ve donanımsal olaraküretiminde aşama kaydedilmiş, çok çeşitli marka\&model piyasaya sürülmüştür. Yıllar içerisinde bir çok e-kitap okuyucu varlık göstermesine karşın zaman içerisinde bazı modeller teknolojik gelişmelere yenik düşerek piyasadan kalkmıştır. Bugün en çok tercih edilen e-kitap okuyucular arasında Amazon Kindle, Barnes \& Noble Nook, Kobo sayılabilir. Ayrıca kitap okuma amacı temelinde çalışmasının yanı sıra çoklu ortam özellikli Apple Ipad, Google Nexus 7 ve çeşitli markaların Android işletim sistemine sahip tabletleri gibi çok amaçlı cihazlarda bulunmaktadır (Görsel 1). Kindle, Nook gibi birincil görevi e-kitap görüntüleme olan cihazların büyük çoğu monokromatik siyah/beyaz e-mürekkep ekranlara sahiptir. Bu sayede LCD renkli ekrana sahip rakiplerine oranla, göz yormayan ekran, metinlerdeki yazı tipinin daha iyi görüntülenmesi ve uzun pil ömrü konforunu okurlarına sunmaktadır. Aynı cihazlarda ikincil olarak gazete ve dergi abonelikleri yapılabilmekte, müzik dinlenebilmektedir

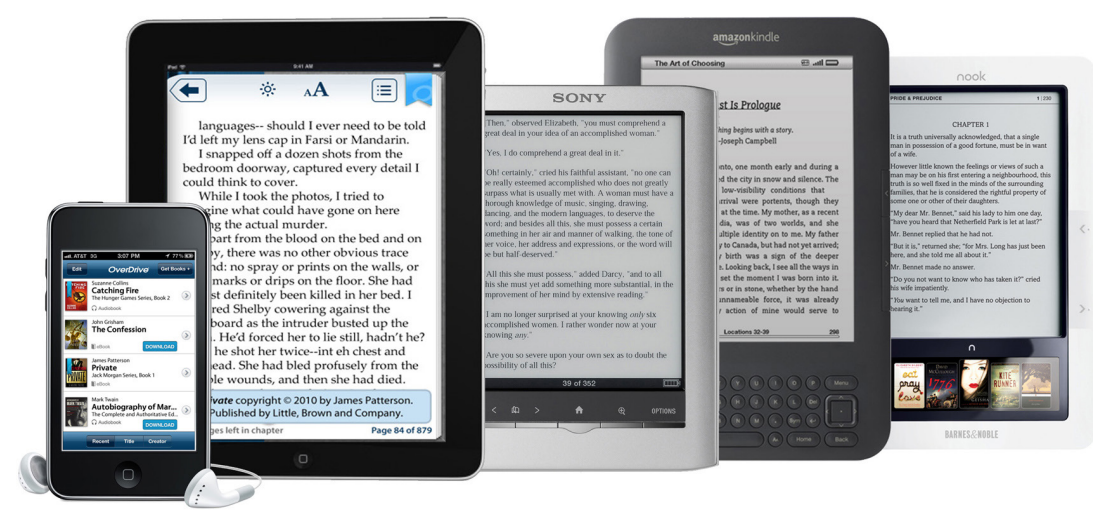

Görsel I. E-kitap okuyucu cihazlar ve tabletlere ait görüntüler.

Elektronik kitabın tanımlanması konusunda çok çeşitli kaynaklarda farkı görüşler bulunduğundan; e-kitabın donanım mı, yazılım mı yoksa içerik mi ya da bunlardan birkaçının bileșimi olup olmadığı noktasında da kavram çeşitliliği mevcuttur. Önder'in konuyla ilgili çalışmasında farklı görüşlere yer verdiği e-kitap tanımlarından bir kaçı şu şekildedir; Weberve Cavanaugh'un tanımına göre (2006) "masaüstü bilgisayarlar, dizüstü bilgisayarlar/elde taşınabilen aletlerde (Personel Digital Assistant - PDA) görüntülenebilen ve resim, animasyon, ses, müzik, video ve hyperlinkleri içeren çoklu model özellikleri sağlayan elektronik yayındır." Armstrong, Edwards ve Londsdale
(2002) "herhangi bir elektronik metnin -büyüklüğüne ve yapısına bakılmaksızın (süreli yayınlar da dahil) - ekranı bulunan herhangi bir aygıt için (elde taşınabilen veya masaüstü) elektronik (ya da optik) olarak hazır bulundurulmasıdır." Morgan'a (1999) göre, "e-kitap özel tasarlanmış taşınabilir aletlerde elektronik verinin okunmasını sağlayan yazılım ve donanım kombinasyonudur." (Akt. Önder ve Atılgan, 2010:176).

Bunlar ve daha bir çok ifadenin ışığında bugünün e-kitabına ait genel bir tanım gerekirse; ekrana sahip herhangi bir aygıtta, özel yazılımlar sayesinde görüntülenebilen, donanımın sağladığı okur dostu olanaklara ek olarak ara-bul, işaretleme, not alma, sözlük gibi gelişmiş zengin metin özelliklerin de yer aldığı, çoklu ortam ögeleri ile ileri düzey işlevlere sahip elektronik bir içeriktir. Daha gelişmiş biçimlerinde ise basılı kitapların tüm özelliklerinin yanı sıra ses, görüntü, film, çoklu ortam becerileri ve etkileşimli bağlantıları da içeren sayısal formata çevrilmiş medya biçimidir.

E-kitaplar yayımcı - yazar - okur açısından bir çok olumlu özelliğe sahiptir. Yayımcılar ve/veya dağııımcılar e-kitaba basılı yayınlara göre daha az bütçe ayırmakta, yayın listelerini ve yazar sayılarını sürekli geliştirebilmektedir. Basılı ve elektronik kitap karşılastırıldı̆ıında e-kitabın avantajları arasında üretim maliyetlerinin düşük olmasının yanı sıra satış kaynaklı maddi kayıp risklerini en aza indirmesi, depolama/dağıtım giderlerini ortadan kaldırması sayılabilir. Yazarlar açısından yorucu ve masraflı olan kitap yayınlama sürecini ise kolaylaştırarak, istediği içerik ve sayfa sayısındaki eserini okurlarıla paylaşabilme şansını vermektedir. Bunun yanı sıra kitap metninde düzeltme ve/veya güncelleme gereği olduğunda, kitabın en son baskısı yeni içeriğiyle yayınlanabilmektedir. Okurlar açısından avantajı ise; bugün bir çoğu ücretsiz veya abonelik sisteminde çalışan 7/24 erişime sahip web sitelerinden indirilen farklı konulardaki onbinlerce e-kitabın bir arada olduğu dijital kütüphaneye sahip olarak tümünü her an yanında taşıyabilmesidir. Okuduğu kitap üzerine istediği kadar not alıp, kelimeleri renkli vurgulayabilmekte, çevrimiçi/çevrimdışı sözlükten kelime anlamı sorgulayabilmekte, yazının büyüklüğünü, rengini, sayfa biçimini en rahat okuyacağı şekilde kişiselleştirebilmektedir. Ayrıca sesli okuma özelliği bir çok görme sorunu olan okura kolaylık sağlayabilmektedir.

E-kitapların sahip olduğu avantajlı yönlerin yanı sıra dezavantajlarından bahsetmek gerekirse; kullanııının hem yazılım hem de donanım kullanımı hakkında gerekli bilgi ve beceri gerekliliği, cihazların pil kapasitesinin sınırlı olması, ekrandan okumanın zorlukları, bilginin güvenilirliği ve telif sorunları sayılabilir. Konuyla ilgili Walton'ın (2007: 96) basılı ve elektronik kitabın kıyaslanmasına ait yorumu şu şekildedir; "e-kitap basılı kitaba 
göre daha mı avantajlıdır? sorusuna basitçe hem evet hem hayır cevabı verilebilir. E-kitaplar; dijital, taşınabilir, aranabilir, ölçeklendirilebilir olması ile avantajlı; göz yorması, okunma zorluğu, ekran bağlımlılı̆̆ı gibi özellikleri ile dezavantajıdır. Burada yapılacak karşılaştırmanın kullanıcının bakış açısı tarafından değerlendirilmesi en doğrusudur." Sonuçta e-kitaplar temel olarak güncellenebilirlik, taşınabilirlik, evrensel erişim ve çoklu ortam özellikleri ile kullanıcı için yepyeni ve heyecan verici bir deneyim yaşama şansı verdiği şüphesizdir.

Economist'te yayımlanan Pricewaterhouse Coopers'ın 2014 yılındaki veriler ısı̆ğında 2018 tahmini rakamlarını içeren kitap pazarının gelişimi hakkındaki araştırmasına göre (Görsel 2); ABD'de halen 5.7 milyar dolarlık güce sahip olan e-kitap endüstrisi ve 10 milyar dolarlık basılı kitap pazarına ait rakamların, 2018 yılında 7.9 milyar dolar (e-kitap) ve 8.7 milyar dolar (basılı kitap) olarak değişeceği tahmin ediliyordu³. Bugünün teknolojik gelişmeleri tüketicinin kitap okuma şekli de dahil olmak üzere hayatında mobilize yönde önemli değişikliklere neden oldu. Medya tüketim alışkanlıklarındaki bu değişim, kitap endüstrisini de doğrudan etkileyerek e-kitap satışlarının küresel kitap satışlarının yaklaşık dörtte birini oluşturduğu, 2018 yılı sonunda 20 milyar dolar gelir getirmesi beklenen verimli bir pazar seviyesine çıkarmıştı̊.

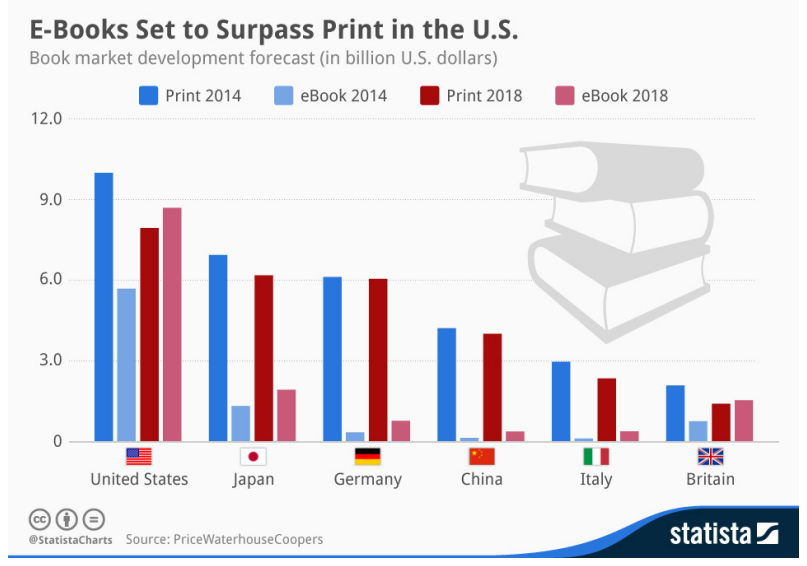

Görsel 2. Basılı kitaplar ve e-kitap pazarı oranları grafiği

${ }^{3}$ E-Books Set to Surpass Print in the U.S. (2015). Web: https://www.statista.com/chart/2823/ book-market-development-forecast/ adresinden I8 Mayıs 20/8'de alınmıştır.

${ }^{4}$ E-books - Statistics \& Facts. (2018). Web: https://www.statista.com/topics/I 474/e-books/ adresin${ }^{4}$ E-books - Statistics \& Facts. (2018
den 10 Mart 2018'de alınmıstır.
Findler (1997: 23); elektronik medyanın gelişimini ve zaman içerisindeki biçimlenişini, kendiliğinden ve bağımsız olarak değil geleneksel medyanın başkalaşım geçirmesi ile ortaya çıktığını ayrıca iletişim sistemlerinin bir bütün olarak incelendiğinde eski biçimlerinin yok olmadığını, değişmeyi ve uyum sağlamayı sürdürdüğünü savunmaktadır. Buradan yola çıkarak gelecekte basılı kitapların tamamen yerini e-kitaplara bırakacağını düşünmek hayali olsa da, günümüzde artan oranda talep gördüğü bir gerçektir. Sadece okuma amaçlı roman, deneme, şiir içerikli kitaplar değil eğitim amaçlı bir çok yayın da elektronik biçime dönüştürülmekte hatta bazı üniversiteler öğrenci ders kitapları için dijital kütüphanelerini oluşturmaktadır. Ayrıca metin beraberinde ses, görüntü, canlandırma, çoklu ortam ve etkileşim özelliklerine sahip örneklerin giderek artması, bu mecralar için artık okunabilen yerine izlenebilen ifadesini dilimize yerleştirmiştir. Rogers (2001) ve Soules (2008) tarafından yapılan çalışmaların sonuçları da öğrencilerin elektronik ders kitaplarının etkileșimli ve kissisel kullanıma uygun olmalarını istediklerini, PDF veya HTML türündeki metin ağıllıklı e-kitaplara ilgi duymayarak, arama seçeneklerinin sunulduğu, kişiselleştirilebilir arayüze sahip ve etkileşimli öğeler içeren e-kitapları tercih ettiklerini göstermektedir. Etkileşimden uzak e-kitapların günümüz öğrencisinin beklentilerini karşılamadı̆̆ı ve bu tür kitaplarda yer verilebilecek canlandırmalar, oyunlar, video görüntüler, kısa filmler, karikatürler ve fotoğraflar gibi etkileşimli öğeler ile farklı öğrenme stillerine sahip öğrencilerin en uygun öğrenme ortamını oluşturmaları kolaylaşacaktır (Akt. Öngöz, 2011: 153).

Kitap, çocuğun gelişim sürecinde bütünleyici bir araç olarak okul öncesi yıllardan başlayarak bilişsel ve dilsel gelişimine katkı sağladığı gibi duygusal ve sosyal yönden gelişimine de destek vermektedir. Bu nedenle; içerik ve dil yönünden nitelikli çocuk kitabı yazımı, resimlemesi ve sunumu son derece önem taşımaktadır (Çatal, 2008: 158). Bugün ise taşınabilir cihazların yaygınlaşması, etkileşim özelliklerine sahip ürünlerin çoğalması ve çevresel uyaracıların artışı çocukların gerek eğitici gerekse eğlendirici amaçlı yeni uygulamalara olan merakını arttırmaktadır. Bu amaçla araştırmacılar, çocukların sorgulama becerisini yükselten, yaratıclıklarını geliştiren eğitici-öğretici etkileşimli uygulamalar, oyunlar ve yeni hikaye anlatım biçimlerinin geliştirilmesine ağırlık vermektedir. Özellikle okul öncesi ve ilköğretim çağındaki çocukların eğitimine yönelik hazırlanan elektronik kitapların sayısındaki artış, bu kitapların üretim sürecinde uzman görüşlerin liderliğinde, hassas ve dikkatli bir çalışmanın önemini gözler önüne sermektedir. Araştırmanın bundan sonraki bölümü belirtilen hedef kitleyeyönelikyayınlanan e-kitap uygulamalarından seçilenlerin, resimleme tekniğinden tipografik düzenlemesine, etkileşim özelliklerinden çoklu ortam ögelerinin kullanımına kadar grafik tasarım açııından incelenmesi 


\section{ve değerlendirilmesine ait sonuçları içermektedir.}

\section{Çocuklara Yönelik Etkileşimli E-Kitap Uygulamaları}

Kültürel, sanatsal, bilimsel, edebi içerikli çok çeşitli konuda tasarlanan çoklu ortam özellikli e-kitap uygulamaları sayesinde okul öncesi çağındaki çocuk, kendisine yönelik hazırlanan bir kitabı dinleyebilme, izleyebilme, kontrol edebilme ve ebeveyni ile birlikte okuyabilme olanağına sahiptir. Bu uygulamaların çoğunda sunulan metinlerin oku - dinle eylemlerinin bir arada yapılabilmesi, hikaye metinlerinin alt yazı üzerinden takibi, ebeveynin okuma ses / görüntülerini kaydedilmesi gibi özellikler çocuğun dil gelişimini olumlu yönde etkilemektedir. E-kitaplar, farklı yaş gruplarından çocuklara göre çok çeşitli içeriklerde bulunabilmekle beraber, özellikle 0-6 yaş aralığındaki küçük çocuklara yönelik tasarlanan etkileşimli uygulamaların sayısı oldukça fazladır. Okul öncesi için etkili bir eğitim materyali olan bu dijital uygulamalardan taşınabilir cihazlara yönelik\&ücretsiz indirilebilen, yaratıcı tasarım ve başarılı etkileşim özelliklerine sahip iyi örnekler gün geçtikçe artmaktadır. Bu çeşit uygulamaların bilinen e-kitaplardan farklı olarak çocuğun öğrenme becerilerini ve hayal gücünü geliştirecek nitelikteki içerik, resimleme, canlandırma, ses/müzik, tasarım ögelerine ve iyi tasarlanmış etkileşim yapısına sahip olması esastır.

4-8 yaş grubuna yönelik Cinderella örneği (Görsel 3) resimleme, canlandırma ve özgün müzik tasarımı ile 2011 \& 2012 yıllarında sayısız ödüllere sahip başarılı bir uygulamadır. Kitabın açılışındaki tercihler ile hikaye istenirse çocuk tarafından okunabilmekte, istenirse yazılım tarafından seslendirilerek okunan kelimelerde renk vurgusu ile ses-yazı eşlemesi sağlanmaktadır. Klasik hikayenin anlatımı sırasında beliren etkileşimli uygulama ekleri, okurun Cinderella'ya mutfağı temizlemesinden, baloya hazırlanmasına kadar farklı sahnelerde yardımcı olması istenmektedir. Böylece, çocukların sayfa içerisindeki tüm görsellere dikkat etmesi ve onlarla etkileşimde bulunarak hikayeye katkısı beklenmektedir. İlgiyi üst seviyede tutarak, çocuğun hikayenin parçası olabilmesi amacıyla cihazın yerleşik kamerasından alınan okura ait görüntü yer yer hikayenin uygun görsel parçalarına (ayna gibi) dahil edilmektedir. Bu örnekte olduğu gibi dijital kitaplarda metne ek olarak ses, görüntü ve canlandırma gibi çoklu ortam özelliklerinin kullanımı çocukların hayal dünyasının gelişiminin yanı sıra olayları, başlangıcı ve sonucu yerli yerine koyarak anlatma becerisinin kazandırılmasında da etkin rol oynamaktadır. Yaşına uygun seçilmiş bir e-yayının etkileşim özellikleri, hikayeye adapte edilmiş geliştirici uygulamaların çocuğun yaratıcılığının gelişimine katkısı büyüktür.
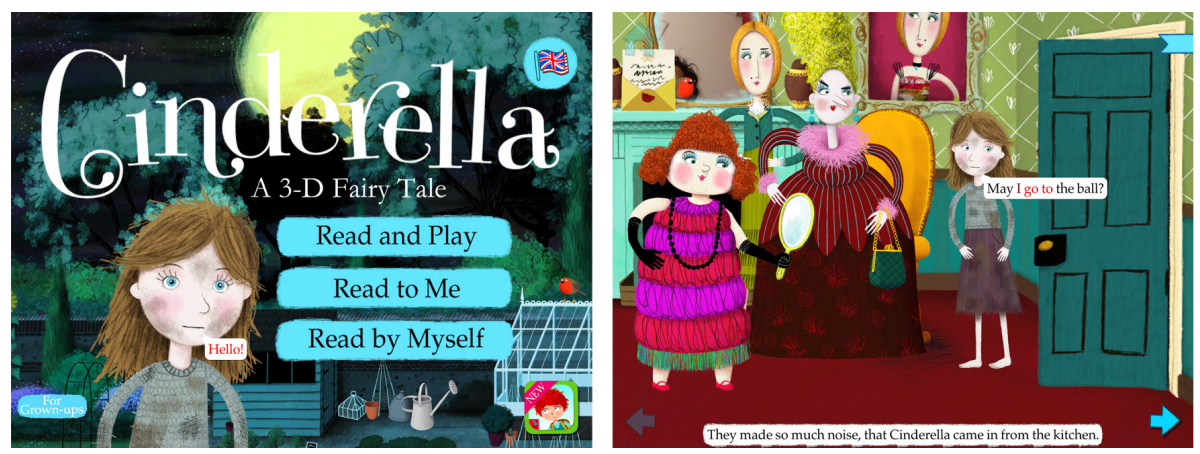

Görsel 3. "Cinderella” e-kitap uygulaması arayüzü.

Çocukların merak ettikleri herşeyi dokunarak keşfetmesi Rom and The Whale of Dreams isimli uygulamanın temelini oluşturmaktadır. Hikaye kimsenin rüya görmediği Numia adındaki topraklarda yaşayan Rom ismindeki çingene prens ve onun düşlediği kelebek kanatlı, aslan patili bir balinanın maceralarını anlatmaktadır. Kitap resimleme, seslendirme, müzik ve etkileşim tasarımı açılarından başarılıdır. Çalışmaya ait görselden (Görsel 4 sol) anlaşılacağı üzere tümü siyah-beyaz renkte tasarlanan sayfanın üzerinde çocuğun parmağını gezdirdiği alanlar renklenerek basit ama çarpıcı bir etkileşim tecrübesi yaşatmaktadır. Bu şekilde sayfadaki diğer renkleri keşfetme heyecanı ve kontrol gücünün kendinde olduğunun bilincindeki çocuk, kitaptaki tüm görseller üzerinde tek tek düşünüp hafızasına kaydetmektedir. Kitap uygulaması tipografik düzenleme bakımından riskli bir örnektir çünkü görsel tasarımda tercih edilen metin düzenlemesi her sahnede fazla değiškenliğe sahiptir bu durum zaman zaman takip-okuma zorluğuna neden olabilmektedir (Görsel 4-Sağ). Bunun yanı sıra hikayenin uygun noktalarında okuyan sesin yer yer heyecanlı/korkutucu vurgu değişimi, cümlelerin arka plan sesine göre hareketlenmesi ise ilgi çekicidir.
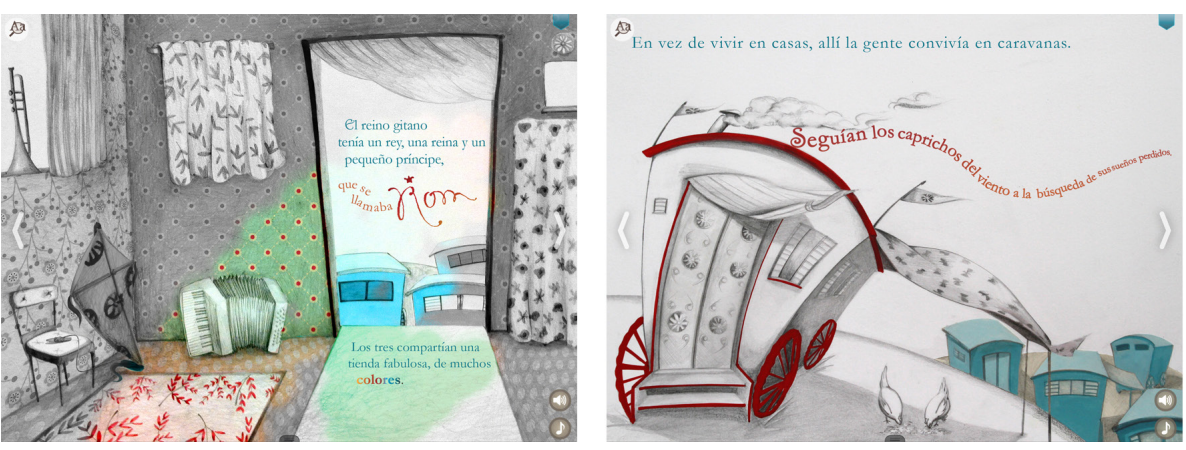

Görsel 4. "Rom and The Whale of Dreams" e-kitap uygulaması arayüzü. 
Goodnight Safari örneğinde (Görsel 5) Afrika'da yaşam süren hayvanlar aleminden kesitler resmedilmektedir. Seçilen canlıların temel türlerine ait özelliklerin betimlendiği basithikayenin her cümlesinden sonra ilgili bölüme ait bir soru kalıbıyla çocuğun kitaba katkısı beklenmektedir. "Zürafanın akşam yemeğini yemesine yardımcı olurmusun?" sorusuna cevap veren kullanıc ekrandaki zürafaya tıklayarak ağaç yapraklarına ulaşmasını sağlamakta, hikayenin akışına dahil olmaktadır. Karışık renkli, savana arka plan temalı görsel düzenlemeye sahip hikayede yer alan "Zebra'nın annesini bulmasına yardımcı olur musun?" soru cümlesi ile çocuk arabul komutlarını geliştiren bir etkileşim deneyimi yaşamaktadır. Örnekte görüldüğü gibi okuma eylemi oyun ile birleştirildiğinde çocuğa sıkılmadan, ilgisini en üst seviyede tutacağı bir öğretim becerisi yaşatılabilir. Böylece çocuk gelecekte okuma eylemini, oyuncaklarından alışkın olduğu etkileşim becerisi ile paralellik kurarak keyif aldığı bir aktivite olarak hatırlayacaktır.

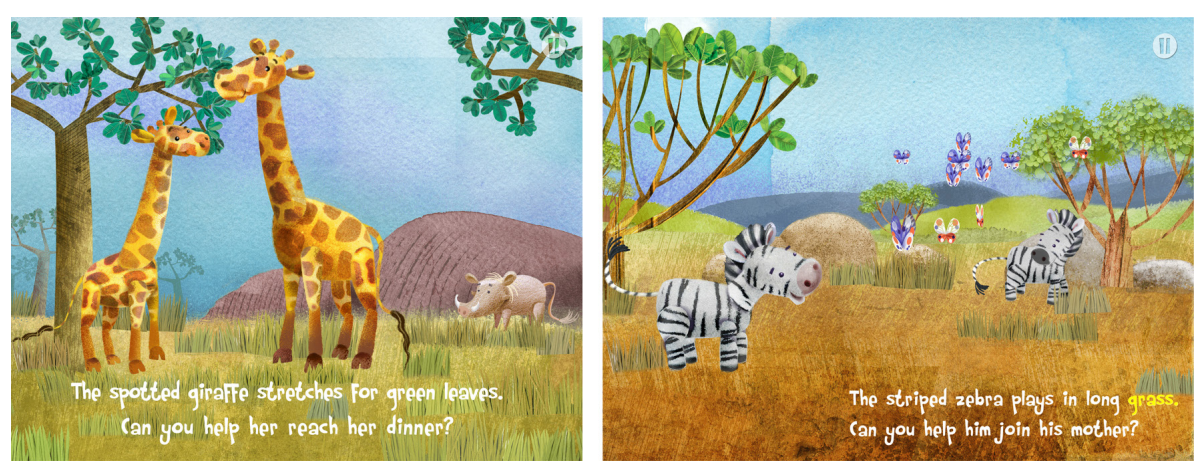

Görsel 5. “íyi Geceler Safari” e-kitap uygulaması arayüzü

Elektronik görüntü alanı olan ekran, insan gözünün yaptığı sınırlandırmaya benzer şekilde, yatayda daha fazla, dikeyde daha az uzunluk içeren bir yöneliştir. E-kitapların görüntülenme ortamı ekranlar, akıllı telefonlar, tabletler ve bilgisayarlara kadar çok çeşitli boyutta ve çözünürlüğe sahip biçimde olabilirler. Kitapta kullanılan yazı karakterlerinin temel özellikleri, resimleme ve renk paleti tercihi ise bu çeşitliliğe göre her cihaz için özel olarak belirlenmelidir. Yayın ortamına özel tasarlanan çalışma, doğru boyut ve yeterli boșluk anlayıșı ile metnin ve görsellerin hızlı algılanmasına, kolay takip edilmesine hizmeteder. Ayrıca sayfadaki görsel veyazınsal her öge tekil olarak doğru tasarlandığı kadar, birbirleriyle oluşturduğu uyum anlamında da sayfanın tasarım bütünlüğüne katkı sağlamalıdır. Çilek Dünyası isimli kitaba ait görsellerde (Görsel 6) sayfadaki resimlemenin yatay\&dikey durumuna göre tercih edilen tipografik düzenleme ve boşluk anlayışı farkı göze çarpmaktadır. Soldaki görselde dikeye yakın komposizyondaki resimleme dar metin sütunu ile birlikte kullanıımışır. Parçalar ayrı ayrı etkili ve rahat algılanır görünmesine karşın, metnin resimleme ile yumuşak bir geçiş sağlamaması, beyazzeminin tasarlanmış bir alan olarak kullanılmaması sayfadaki tasarım bütünlüğünü zayıflatmaktadır. Sağdaki görselde ise metin, resimlemenin eşlikçisi ve aynı zamanda bütünün parçası olma hissini başarılı biçimde vermektedir. Bunun yanı sıra metinde kullanılan satırların uzunluğu ve her sayfada değişken olması önemli bir hatadır. Çünkü "yazı karakteri ölçüsü ne olursa olsun bir metinde satır başına boşluk dahil 5080 karakter karşılığı yaklaşık 8-12 sözcük algılanabilmektedir. Bu değerlere bağlı olarak paragraf genişliği hesaplanır. Paragrafdaki satır uzunluğu satır arası boşluğa ve takibe etki etmektedir." (Samara, 2005: 37).
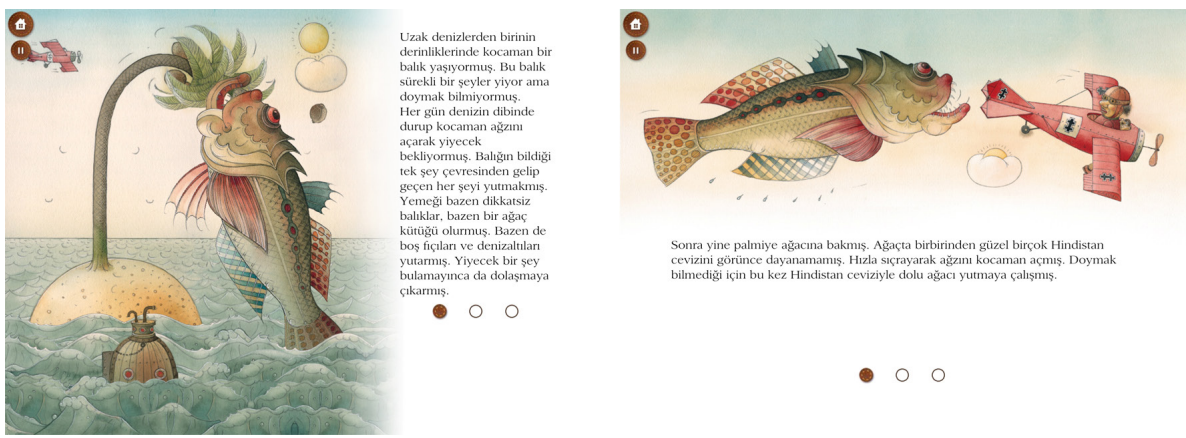

Görsel 6. "Çilek Dünyası” e-kitap uygulaması arayüzü.

Sayfatasarımı, bilginin okunabilir, ilgiçekicive etkilibiçimde düzenlenmesidir. Bir yayın sadece içeriğiyle değil, sayfa düzenleme biçimiyle de kendini tanıtır ve okutturur. Bu sebeple yazı, fotoğraf, resimleme gibi tasarım ögelerinin yayımlanacağı ortamın özellikleri çerçevesinde nasıl tasarlandığı ve sunulduğu büyük önem taşımaktadır. Tüm bu ögelerin birbiriyle ilişkisi ise kitabın görsel kimlik biçimini olumlu/olumsuz etkilemektedir. Iyyi bir çocuk kitabı, konusu doğrultusunda görselleştirilen resimlemelerle, çocuğu bilgilendirmeyi, eğitmeyi, fantezi ve düş kurdurmayı amaçlar niteliktedir. Resimleme sanatçısı ve öğretim üyesi Nazan Erkmen'e göre; "duygu yüklü illüstrasyonlar çocukta ona katılma duygusunu uyandırırlar. Sanat değeri olan resimlemeler çocukta okuma dürtüsünü oluşturacaktır. Çocuk bu resimlemelerin altını, sayfanın devamını okumak isteyecektir. Sağlam sezgilere ve eleştirel gözlemelere sahip olan çocuklardaki entelektüel oluşumlar ancak kaliteli resimlerin yardımı ile güçlenecektir. ${ }^{5 "}$ Resimli çocuk kitapları yazılı ya da yazısız olsun, çocuğun metni daha hızlı ve doğru algılamasına, içeriğin hedefe daha kolay ulaşabilmesine hizmet etmektedir.

${ }^{5}$ Çellek, T. (2003) Kitap Resimlerinin Canı Nazan Erkmen (Röportaj) Web: http://www.tulaycellek. com/tulay/eser asp?id=268 adresinden 20 SSubat 2017 'de alınmıstur. 
Tasarımda görsel iletişim imgelerinin kurgusunda hedef kitlenin hangi yaş aralığında olduğunun belirlenmesi son derece önemlidir. Burdan yola çıkarak tasarlanan kitap tasarımları yaşa uygun yönlendirmeler içermeli, kullanılan komutlar anlaşılır ve hatırlanması kolay, aynı zamanda etkileşimi yüksek seviyede, dikkat çekici ve ilgi uyandırıcı olmalıdır. Zoe's Green Planet örneğinde (Görsel 7) yeşil bir gezegende yaşayan Zoe ve ailesinin kırmızı gezegenden gelenyenidostlarıylatanışmasıveyaşadıklarıresmedilmektedir. Tasarım ögelerinden rengin ayrıştııcı etkisinin çarpıcı şekilde kullanımı, resimleme dili'nin özgünlüğü, düğmelerin tasarımı ve seçilen okuma sesinin etkisi ile kitap başarılı bir örnektir. Yönlendirme düğmeleri, çocuğun rahatlıkla kullanabileceği büyüklükte göze çarpmakta, verilen komuta ait eylemin doğal yönünü destekleyecek biçimdeki minik hareketlere sahip, doğru bir etkileşim tasarımıdır. Sayfadaki hikaye metinlerinin sonunda "yer küreyi çevirebilirsin!", "mekiğin uçmasına yardım edermisin?" gibi temel soru/komutlar ile okurun etkileșime girmesi gereken görsel elemanlara ve eylemlere uygun bir yönelim sağlanmaktır. Çocuğun dikkatini çekmek ve ilgisini kitap üzerinde toplamak amacıyla kitabın sesli okunması sırasında sayfadaki resimleme ögeleri üzerine tıklama sonucu ses, hareket, renk değişimi gibi doğru etkileşim davranışları bulunmaktadır. Hikayenin akışında ilgili sahneler arasına yerleştirilen küçük bulmaca/yarışmalı oyunlar ise kitabı çocuk için ilgi çekici hale getirmektedir.

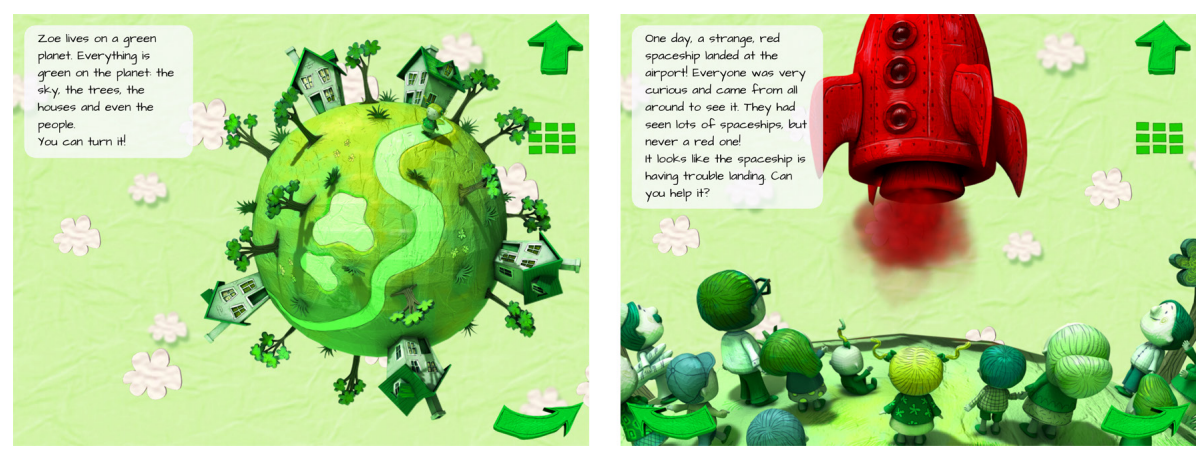

Görsel 7. “Zoe’nin Yeşil Gezegeni” e-kitap uygulaması arayüzü.

Okunabilir tipografi bilgi iletiminde en büyük araçtır. Özellikle metni okutmanın temel unsur olduğu kitap sayfası tasarımında tipografik seçim ve uygulama biçimi büyük önem taşımaktadır. Tipografi bilgi ve mesajın amacına uygun bir biçim diliyle iletilmesinin yanı sıra bir biçem, kimlik, görsel bir dil olabilme gücüdür. Yazının biçiminden rengine, satır/harf arası boşluk düzeninden görsel ögeler ile ilişkisine kadar her detay sayfa tasarımının parçasıdır. Amacına uygun tasarlanmamıs metin düzenlemesi, algıda, okumada, içerik iletiminde ve kitabın görsel etkisinde kayıplara sebep olmaktadır.

Ekrana yönelik tasarımlar özel yazı karakteri seçimi gerektirmekte, basılı yayınlarda rahatça okunan tırnaklı (serifli) yazı karakterlerinin ince detayları, ekranın görüntü işlemesinden kaynaklanan bozulmalar nedeniyle elektronik yayınlarda okuma sorunları oluşturabilmektedir. Bunun gibi mecralarda mutlaka okunurluğu yüksek, harf anatomileri ve boşlukları ekrana özel düzenlenmiş mümkünse tırnaksız yazı karakterleri tercih edilmelidir. Sayfada kullanılan yazı karakteri, puntosu, harf ve satı arası boşluklarııı doğru planlanması kolay okunurluğun temel ip uçlarıdır. Bu tipografik ögeler kitabın hitap ettiği yaş grubuna, metnin oluşturduğu gri yoğunluğuna ve birlikte yer aldığı resimlemeye göre değişkenlik gösterebilir. Ayrıca harf ölçüsü belirlenirken, ekran yüzeyi ile göz arasındaki mesafe dikkate alınarak harf büyüklüğünün sözcük sayısını algılamaya etkisi unutulmamalıdır. Ekranın parlak bir ışık zemin olması, e-kitaptaki metinlerin uzun süre bakıldığında gözü yormayan büyüklükte ve rahat okunan bir yazı tipinde olmasını zorunlu hale getirir.

Metni oluşturan cümlelerin çok uzun olmaması çabuk konsantrasyon dağılımına sahip çocuk okurlar için özellikle dikkat edilmesi gereken diğer bir noktadır. Başarıı bir okunabilirlik adına metnin bulunduğu alan, yazının ölçüsü, satılların uzunluğu, sütunların yapısı ve sayfa içindeki boşluklar dikkatle hesaplanmalıdır. Küçük Kaz Cambaz İstanbul'da örneği (Görsel 8) sayfa tasarımı; yazı karakteri, renk seçimleri, zemin-metin ilişkisi açılarından değerlendirildiğinde yukarıda bahsedilen bir çok noktada eksikleri göze çarpmaktadır. Tırnaklı seçilen yazı karakteri ile düzenlenen metinde cümlelerin zaman zaman kavisli bazen düz yerleşimi, hizalamanın sola ve sağa sürekli değişken yapısı okumayı zorlaştırmaktadır. Metinlerin sütun genişlikleri, sayfadaki boşluklara yerleşimi ve görseller ile ilişkisi açısından doğru tasarlanmaması sebebiyle hikayenin okuma yönüne dair ciddi bi karmaşa mevcuttur. Resimlemenin detayları ve arka plan renkleri arasında cümleler zor algılanmaktadır. Yazı büyüklüklerinin belli bir standarta sahip olmaması, seçilen yazı karakterinden kaynaklı düzenlenmemiş ligatür (ardışık kullanıldıkları zaman, anatomik problemler oluşturan karakterlerin bağları - örneğin $f$ ve I harflerinin yan yana kullanımında fl bitişik yeni bir form oluşması), vurgu amacıyla aynı anda hem büyük/küçük punto hemde normal/kalın biçem kullanımına dayalı ciddi okunma sorunları dikkati çekmektedir. 

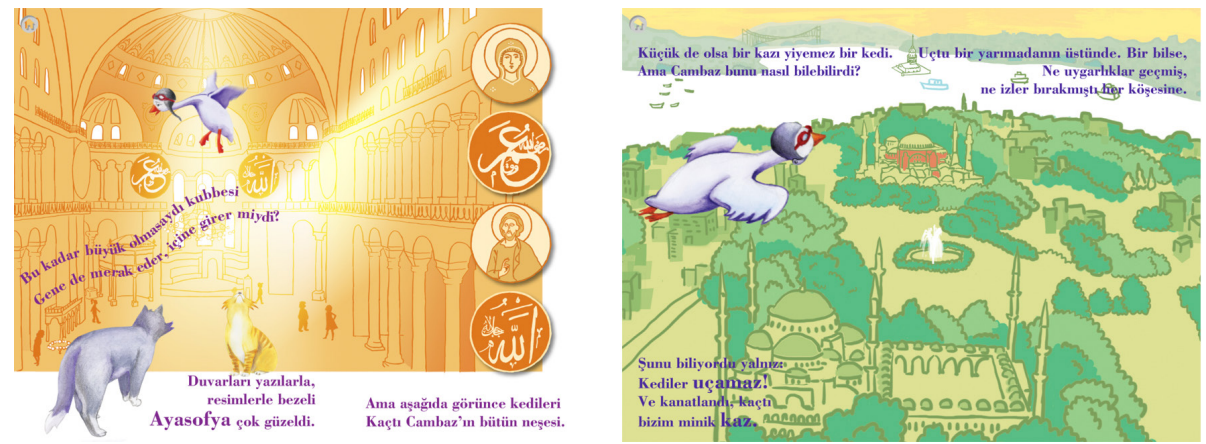

Görsel 8. "Küçük Kaz Cambaz İstanbul'da” e-kitap uygulaması arayüzü.

Ekrana yönelik bir tasarım için seçilen her rengin algı üzerindeki psikolojik etkisinin anlamını bilmek önemlidir. Renk seçimi, hedef kitlenin yaşına, resimlenecek kitabın türüne, olay örgüsünün geçtiği yer/zamana göre değişiklik göstermektedir. Özellikle çocuklara yönelik bir çalışmada canlı\&parlak renk kullanımı, renklerin kontrast ve uyumuna dikkat edilmelidir. Ayrıca renklerin sıcak/soğuk ve açık/koyu oranları farklı mesajları iletmek ya da vurgulama gibi ayrı amaçlar için kullanılabilir. Metnin düzenlemesinde renk kullanımı açısından açık ton zemin üzerinde koyu renk yazı seçimi, koyu ton zemin üzerinde açık renk yazıya oranla daha rahat okunur. Bu sebeple arka plan rengi veya dokusu içinde kaybolmayan bir yazı tipi, renk seçimi dikkat ve özenle çalışımalıdır.

\section{Sonuç}

Birçok ortak özelliği paylaşan basılı ve elektronik ortam yayınları, yayının sunulduğu ortama, bilginin üretimine ve güncellenme biçimine göre kendine özgü temel farklılıkları da içermektedir. Elektronik kitaplar ise her tür bilgisayar, taşınabilir e-kitap okuyucu ve akıllı telefonda kısaca ekrana sahip cihazda okunmak üzere tasarlanmış, çeşitli avantajları olduğu kadar geliştirilmesi gereken noktaları da bulunan basılı kitapların yerini almaktan çok onun yanında pozitif bir seçenek olarak algılanmalıdır. Günümüzde e-cihazların küçük yaşlardan itibaren cocukların yașamında etkin rol oynaması, uyaranların çeşitliliği ve her daim yeni olanı keşfetme merakı sayesinde iletişim alışkanlıklarının değişim ve gelişimi kaçınılmazdır. Bu süreçte geleceğin okurları olan çocuklara yönelik eğitici-öğretici e-kitap ve dijital uygulamaların doğru içerik\&görsel tasarıma sahip, kişisel gelişimlerine katkı sağlar bütünlükte üretilmesi önemlidir. Ozellikle etkileşim tasarımının öne çıktığı bu tip uygulamalarda çocuklara ait tepki ve davranış biçimlerinin detaylı şekilde araştırlıp, yapılan çalışmanın bu doğrultuda hedef kitleye doğru aktarıması gerekir.
Araştırmada tasarım açısından incelenen çocuklara yönelik kitap uygulamaları göstermiştir ki; resimleme dilindeki çeşitlilik ve özgünlük, hayal gücünü arttıııı kompozisyon anlayışı, etkileşim özelliklerinin doğru ve yerinde kullanımı ile başarılı çalışmalara imza atmak mümkündür. Çocuklara yönelik eğitici ve hikaye anlatımlı kitap uygulamaları e-yayın dünyası için etkili bir pazardır. Peki bu başarıı çalışmaların kullanıcı açısından tercih edilmesinde ana unsur nedir? İncelenen başarılı örneklerin hemen hepsinin arkasında; yazarlar ile birlikte alan uzmanı kisilerden seçilen çocuk gelişimcilerin, eğitimcilerin, görsel tasarımcıların, illüstratörlerin ve editörlerin oluşturduğu kalabalıkbir ekibin uzunzaman\&emekalan çalışması yatmaktadır. Ortaya çıkan kitap uygulamasının kalitesi, başarıya ulaşması noktasında yayıncı kuruluşlara da özel uzmanlık gerektiren bu alanlara yeterli bütçeyi ayırma ve gereken çalışma zamanııın tanınması noktasında büyük görevler düşmektedir. Yapılan bu çalışmada sunulan önerilerin amacı, yakın gelecekte kendi dilimizde yazılmış, özgün resimlemelere ve etkili tasarımlara sahip, kaliteli içerikteki başarılı e-yayınların sayııının ülkemizde artmasıdır. 


\section{Kaynakça}

Anameriç, H., Rukancı, F. (2003). "E-kitap Teknolojisi ve Kullanımı”, Türk Kütüphaneciliği Dergisi, 17 (2), I47-I66.

Çatal, D. (2008). “Elektronik Çocuk Kitapları”, Sanat Yazıları, I8, I55-I65.

Fidler, R. (1997). Mediamorphosis: Understanding New Media. California: Pine Forge Press.

Kist, J. (1989). Electronic Publishing. M. Eraut (Ed.). International Encyclopedia of Educational Technology (4). Oxford. Pergamon Press, s.600-608.

Önder, I., Atılgan N. (2010). Elektronik Kitap ve Gelişim Süreci., Umut Al \& Zehro Taşkın (Ed.). Prof. Dr. İrfan Çakın’a Armağan. Ankara. Atalay Matbaacılık, s. I 75- I83.

Öngöz, S. (20II). Bir Öğrenme - Öğretme Aracı Olarak Elektronik Kitap., Zülfü Genç (Ed.). 5th International Computer \& Instructional Technologies Symposium Proceedings Book. Elazı̆̆. Fırat Üniversitesi Matbaası, s. I50-155.

Samara, T. (2005). Publication Design Workbook. U.S.A.: Rockport Publishing.

Walton, W. E. (2007) Faculty and Student Perceptions of Using E-Books in a Small Academic Institution., Hugh A. Thompson (Ed.). ACRL Thirteenth National Conference Proceedings. Baltimore. MD, s. 92-99.

\section{Internet Kaynakları}

Internet: Digital Media. (2018).

Web: https://www.statista.com/outlook/200//00/digital-media/worldwide adresinden 18 Mayıs 2018'de alınmıştır.

Internet: ePublishing. (2018).

Web: https://www.statista.com/outlook/204//00/epublishing/worldwide adresinden 10 Mart 2018'de alınmiştır.

Internet: E-Books Set to Surpass Print in the U.S. (2015).

Web: https://www.statista.com/chart/2823/book-market-development-forecast/ adresinden I8 Mayıs 2018'de alınmıştır.
Internet: E-books - Statistics \& Facts. (20/8).

Web: https://www.statista.com/topics//474/e-books/ adresinden 10 Mart 2018'de alınmıştır.

Internet: Çellek, T. (2003) Kitap Resimlerinin Canı Nazan Erkmen (Röportaj)

Web: http://www.tulaycellek.com/tulay/eser.asp?id=268 adresinden 20 Şubat 20I7'de alınmıştır.

\section{Görsel Kaynakları}

Görsel I. E-kitap okuyucu cihazlar ve tabletlere ait görüntüler (E-book readers and tablets). Good E Reader. http://goodereader.com/blog/digital-library-news/are-e-readersor-tablets-better-for-library-ebooks. Erişim: 15 Şubat 2016.

Görsel 2. Basılı kitaplar ve e-kitap pazarı oranları grafiği (E-books Set to Surpass Print in the U.S). Statista. https://www.statista.com/chart/2823/book-market-developmentforecast. Erişim 15 Şubat 2016.

Görsel 3. "Cinderella" e-kitap uygulaması arayüzü. Nosycrow. http://nosycrow.com/apps/ cinderella. Erişim: 20 Şubat 2017.

Görsel 4. "Rom and The Whale of Dreams" e-kitap uygulaması arayüzü. BelMontis Publication. http://www.romandthewhale.com. Erişim: 12 Mart 2017.

Görsel 5. "Iyi Geceler Safari” e-kitap uygulaması arayüzü. Polk Street Press. http://www. polkstreetpress.com./apps-books/goodnight-safari. Erişim: 12 Mart 2017.

Görsel 6. "Çilek Dünyası” e-kitap uygulaması arayüzü.

(Morpa Kültür Yayınları - www.morpa.com.tr) Erişim: 20 Şubat 2016.

Görsel 7. "Zoe'nin Yeşil Gezegeni” e-kitap uygulaması arayüzü. Square Igloo. http://www. squareigloo.net/en/apps. Erişim: 17 Şubat 2017.

Görsel 8. "Küçük Kaz Cambaz İstanbul'da (The Istanbul Adventure with Bruce the Goose) e-kitap uygulaması arayüzü. Manolin. http://manolin.com.tr/apps/ Erişim: 20 Şubat 2016. 